\title{
A correlation of thyroid hormone receptor gene expression with amphibian metamorphosis
}

\author{
Yoshio Yaoita and Donald D. Brown \\ Department of Embryology, Carnegie Institution of Washington, Baltimore, Maryland 21210 USA
}

\begin{abstract}
The expression of the thyroid hormone (TH) receptor genes $\alpha$ (TR $\alpha$ ) and $\beta$ (TRß) in Xenopus laevis begins after the embryo hatches. The TR $\alpha$ mRNA increases throughout the premetamorphosis stage of tadpole development, is maximal by prometamorphosis, and falls after climax of metamorphosis to a lower level in frogs. The TRß mRNA is barely detectable during premetamorphosis. In synchrony with the onset of endogenous TH synthesis by the thyroid gland (prometamorphosis), the level of TR $\beta$ mRNA rises in parallel with endogenous TH, reaching a peak at the climax of metamorphosis (stage 61 ) and drops to $\sim 10 \%$ of its peak level after metamorphosis. As suggested by this correlation, exogenous TH up-regulates TR $\beta$ mRNA as much as 20 -fold during premetamorphosis, whereas TH up-regulates TR $\alpha$ mRNA by $\sim 2$-fold during the same period. Up-regulation of TRß mRNA is the earliest response to exogenous TH by competent tadpoles yet detected.
\end{abstract}

[Key Words: Xenopus; metamorphosis; thyroid hormone receptor genes; transcription]

Received July 18, 1990; revised version accepted August 31, 1990.

Amphibian metamorphosis is divided into three developmental periods (Dodd and Dodd 1976). Premetamorphosis refers to the development and growth of the tadpole that occurs before formation of a functional thyroid gland. In Xenopus laevis, premetamorphosis ends at about stage 54 (Nieuwkoop and Faber 1956) when the developing thyroid gland begins to secrete thyroid hormone (TH) (Leloup and Buscaglia 1977), the known biological effector of metamorphosis. An orderly succession of morphological changes occurs during the next stage, prometamorphosis (NF55-57), the most obvious of which is limb development. The front legs erupt from the opercular fold, and the shape of a miniature frog is almost complete by the third stage, or climax, when the concentration of endogenous TH is maximal. The final change after stage 62 is a rapid resorption of the tail. These transitions that affect almost every tissue are dependent on the concentration of TH (Kollros 1961), which itself is controlled by a feedback loop connecting the pituitary, the hypothalamus, and the thyroid gland (Etkin 1968).

We began an investigation of this complex process by cloning and characterizing members of the two known thyroid hormone receptor (TR) families $-\alpha$ and $\beta$ (Yaoita et al. 1990). In Xenopus there are two TR $\alpha$ (A and $B$ ) and two TR $\beta$ (A and B) genes. Here, we report the level of TR $\alpha$ and TR $\beta$ mRNAs during Xenopus development and we describe the extent to which their mRNA levels correlate with metamorphosis.
Results

An assay for the TRa and TR $\beta m R N A s$

The major components of both $\operatorname{TR} \alpha$ and TR $\beta$ mRNAs are $\sim 10 \mathrm{~kb}$ in size; they are rare and difficult to detect by traditional Northern blot analysis (Fig. 1). The isolation of poly $(A)^{+}$RNA does not improve the yield of these mRNAs very much, perhaps because of their large sizes. We developed an assay in which the mRNA is converted into cDNA by reverse transcriptase primed by a specific antisense oligonucleotide. The resulting cDNA is electrophoresed, blotted, and hybridized with a radioactive probe, as for a standard Northern blot. This modified primer-extension method has several merits. First, the radioactive signal is from 3 - to 10 -fold greater than that obtained from a Northern blot of an equivalent amount of mRNA. We have found this to be true for the mRNAs for $\operatorname{TR} \alpha$ and $\operatorname{TR} \beta$ and to varying extents for other mRNAs. The augmented signal is due partly to the greater retention of DNA than RNA on filters and partly to the difficulties of working with very high-molecularweight RNA and keeping it intact. The primer extension method, using a primer $3^{\prime}$ to the termination codon, converts a large $10-\mathrm{kb}$ mRNA to a cDNA of $\sim 1.8 \mathrm{~kb}$ (Fig. 1). Because the 5'-untranslated region (UTR) and the coding sequence comprise $\sim 2 \mathrm{~kb}$ (Yaoita et al. 1990), the remaining $8 \mathrm{~kb}$ of these mRNAs must be located in the 3' UTR.

The TR $\alpha$ reverse transcripts are present as a promi- 


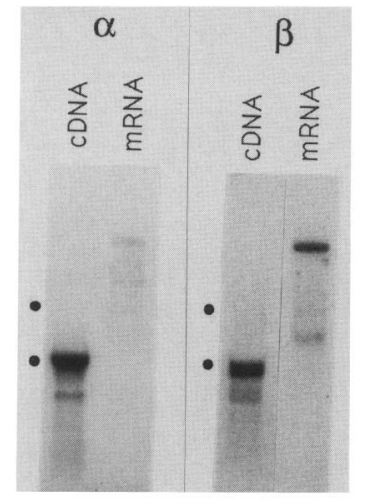

Figure 1. Comparison of Northern blotting and modified primer extension methods for determining transcripts of TR $\alpha$ (left) and TR $\beta$ (right) mRNAs. Either poly $(\mathrm{A})^{+}$RNA $(4 \mu \mathrm{g})$ or cDNA synthesized from $10 \mu \mathrm{g}$ (TR $\alpha$ ) or $7 \mu \mathrm{g}$ (TR $\beta$ ) of total RNA isolated from stage 58 tadpoles was loaded in each lane. (Upper and lower dots| The positions of $28 \mathrm{~S}$ and $18 \mathrm{~S}$ rRNAs, respectively.

nent, single band and a fainter, faster-moving band; transcripts from the two $T R \alpha$ genes are not distinguished in this study. With TR $\beta$ mRNA as template, we detect two pairs of cDNA bands. The more prominent upper pair is located at about the $18 \mathrm{~S}$ rRNA marker; the two bands are barely separated (e.g., see Figs. 3 and 4 , below). A TR $\beta B$-specific probe hybridizes mainly to the lower of these two bands. The TRßA-specific probe hybridizes about equally to both bands of this doublet. These differences between reverse transcripts of TR $\beta A$ and $T R \alpha B$ mRNAs are subtle, and we have not found them useful for distinguishing transcripts from the two TR $\beta$ genes. This must be done with either specific primers or probes (see Fig. 6, below).

The 5' UTR of TR $\beta$ mRNAs is very complex, consisting of eight alternatively spliced exons (Yaoita et al. 1990|, and the identity of each of these cDNA bands with one or more mRNA variants has not been established. The method is sensitive because the probe is labeled fully. The cDNA assay is linear over a wide range of mRNA concentrations, as we have shown in reconstructed systems with known amounts of mRNA /data not shown). Total RNA is used directly for primer extension without first purifying poly $(\mathrm{A})^{+}$RNA.

\section{The developmental expression of TRa and TR $\beta$ genes}

Expression of the TR $\alpha$ and TR $\beta$ genes was measured by the primer-extension method using as template total RNA from whole tadpoles at various stages (Figs. 2 and 9, below). TR $\alpha$ and TR $\beta$ mRNA were not detected in oocytes, eggs, or embryos until after hatching. TR $\alpha$ mRNA increases from stage 38 throughout premetamorphosis, reaching a peak by early prometamorphosis (stage 56); it remains elevated until climax and then decreases to about half of its peak value in frog liver. TR $\beta$ mRNA is low throughout premetamorphosis, rises to a peak at climax, and then falls. The expression pattern of TR $\beta$ mRNA follows closely the concentration of endogenous TH (Leloup and Buscaglia 1977) (see Fig. 9, below). There is a subtle change in the pattern of cDNA bands synthesized from TR $\beta$ mRNA as development proceeds. The slower-migrating of the two cDNA fragments in the upper doublet of bands predominates during premetamorphosis. At about stage 52, the faster-migrating cDNA band is detectable. Transcripts of both TR $\beta$ genes contribute about equally throughout development (see Fig. 6, below).

\section{Exogenous $T H$ up-regulates $T R \beta m R N A$}

The close correlation of TR $\beta$ mRNA with endogenous TH formation by tadpoles suggested that the level of TR $\beta$ mRNA is regulated, in part, by TH concentration. Two-day treatment of embryos from stage 40 with 3,5,3'-triiodo-L-thyronine $\left(\mathrm{T}_{3}\right)$ results in the premature appearance of the faster-moving of the two cDNAs in the upper doublet synthesized from stage 44 RNA, and showed fourfold up-regulation of TR $\beta$ mRNA (Fig. 3). Stage 48 tadpoles treated previously for 6 days with $T_{3}$ had their TR $\beta$ mRNA up-regulated to the level of control stage 61 Xenopus at climax. After stage 48 and throughout premetamorphosis, a 1-day treatment induces a maximal response (Fig. 4). Early morphological changes, such as the growth of hind limbs, are observed at stages 47-48 after continuous exposure to $T_{3}$ and $\sim 1-2$ days after up-regulation of TR $\beta$ mRNA has occurred.

In a competent tadpole during premetamorphosis, TR $\beta$ mRNA up-regulation is detectable $8 \mathrm{hr}$ after the addition of $T_{3}$ to the water; it is maximal after $16 \mathrm{hr}$ (Fig. 4). A much lower extent of TR $\alpha$ mRNA up-regulation (about two- to threefold) also occurs by $8 \mathrm{hr}$ after TH treatment. Another correlation of TR $\beta$ mRNA up-regulation with metamorphosis can be shown by removing exogenous $\mathrm{T}_{3}$ several days after its administration during the premetamorphosis period. The induced morphological changes are arrested, and the level of TR $\beta$ mRNA drops (Fig. 5). Thus, continuous administration of $T_{3}$ is required both for TR $\beta$ mRNA up-regulation and the induction of morphological changes. Up-regulation of both TR $\beta A$ and TR $\beta B$ mRNAs by exogenous $T_{3}$ can be demonstrated in competent tadpoles (Fig. 6). Once metamorphosis has proceeded to climax (stage 62), exogenous $T_{3}$ no longer up-regulates TR $\beta$ mRNA, presumably due to the high levels of endogenous $T_{3}$. In frogs, the level of TR $\beta$ mRNA (and $T_{3}$ ) is lower than the peak concentration at climax, and some up-regulation occurs with exogenous $T_{3}$ (Fig. 6).

\section{Expression of $T R$ in tail and hind limbs}

During prometamorphosis, the hind limbs develop with no change in tail size. At climax (stage 63), the tail regresses rapidly at a time when hind limb development is complete. We compared the TR mRNA content in hind limbs and tail at stages 58 and 63 (Fig. 7). Both TR $\alpha$ and 


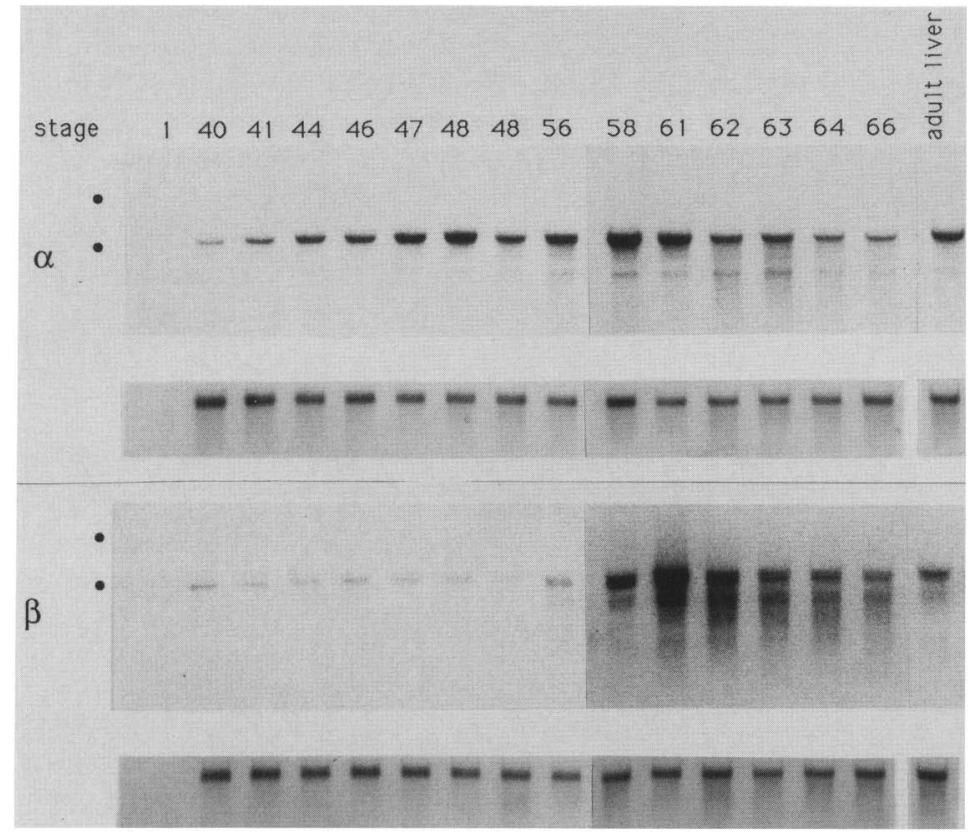

Figure 2. The expression of TR genes during Xenopus development. The cDNA synthesized from $10 \mu \mathrm{g}$ whole tadpole RNA at each stage was loaded in each lane and analyzed using TR $\alpha$ (upper panel) and $\beta$ probes (lower panel). These filters were rehybridized with the RP28 probe to standardize the amount of nucleic acid loaded in each lane, and the results are shown below the TR $\alpha$ and TR $\beta$ panels. The first and second stage 48 samples were from 9- and 13-day-old tadpoles, respectively.
TR $\beta$ mRNAs are elevated in tissues that are in the act of transforming, that is, hind limbs at stage 58 and tail at stage 63.

\section{Correlation of TR mRNAs with metamorphosis of neotenic amphibians}

Some neotenic salamanders such as Necturus maculosus, the mud puppy, remain larval all their life and cannot be induced to metamorphose, even with large doses of exogenous TH (see Dent 1968). Others, such as Ambystoma mexicanum, the axolotl, usually remain larval in nature but can metamorphose spontaneously or be induced to transform with exogenous $\mathrm{TH}$ (Kühn and Jacobs 1989|. Morphological change of a TH-responsive urodele such as the axolotl is more limited than it is in anurans, but one major change is gill resorption.

We measured the levels of TR mRNAs in extracts of gills of Necturus and axolotl as a response to exogenous
$\mathrm{T}_{3}$ treatment. Northern blots probed with cloned Xenopus TR cDNAs did not detect TR mRNAs. In the absence of sequence information, we primed cDNA synthesis from total RNA with oligo(dT) and electrophoresed, blotted, and hybridized the cDNAs with various Xenopus TR cDNAs (Fig. 8). This experiment will only succeed if there is a poly(A) priming site reasonably close to the coding region of the mRNAs. The results show substantial hybridization with the cDNA synthesized from axolotl but not Necturus cDNA. It further shows up-regulation of axolotl TR mRNA of about fourfold following $T_{3}$ injection. Xenopus $\operatorname{TR} \alpha$ and $\operatorname{TR} \beta$ cDNA probes give similar results, so we cannot distinguish which family of TR transcript is being detected by these heterologous probes. The result correlates TR mRNA content with the known responsiveness of axolotl to $T_{3}$ with the caution that this method of measuring heterologous mRNAs of unknown sequence may miss an abundant relevant mRNA altogether.

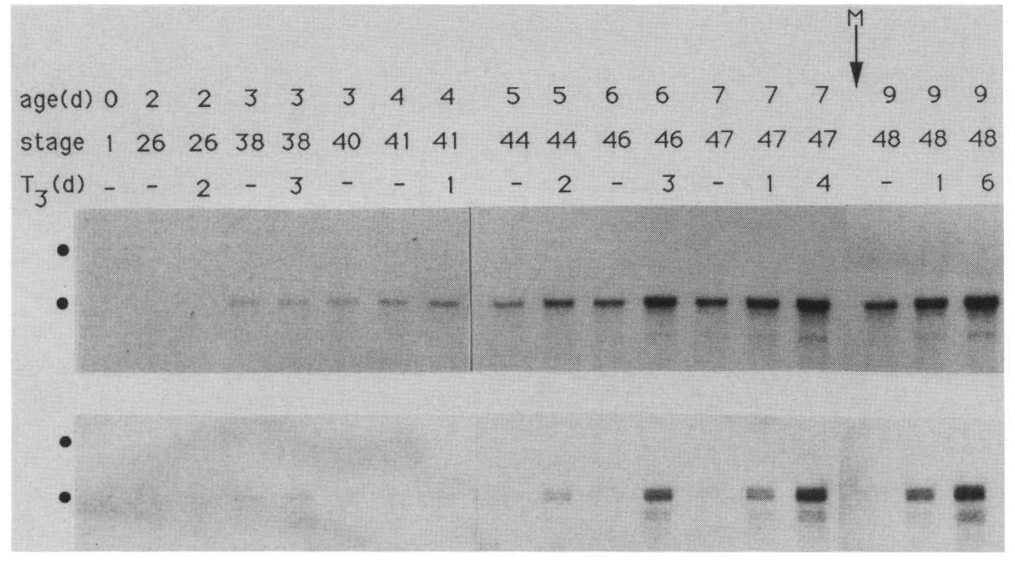

Figure 3. The response of TR genes to $T_{3}$. Embryos and tadpoles were treated with $5 \mathrm{nM} \mathrm{T}_{3}$ for varying periods before RNA was extracted [labeled $\mathrm{T}_{3}$ (d)]. Ages of embryos or tadpoles from the time of fertilization to the time of RNA extraction are represented in days (d). A dash means no treatment with $\mathrm{T}_{3}$. A total of $10 \mu \mathrm{g}$ of whole tadpole RNA was converted to cDNA and one-third of it was loaded in each lane. The arrow marked by $M$ indicates the time when the first morphological change was observed (i.e., 8-day-old tadpole treated for 5 days). The upper panel is probed with TR $\alpha$; the lower panel, with TR $\beta$. 


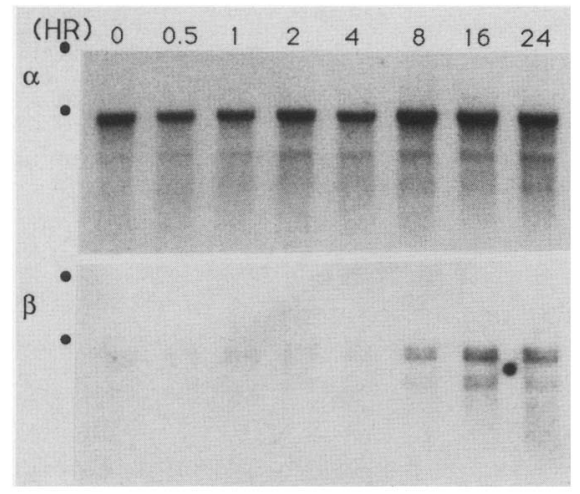

Figure 4. The accumulation of TR mRNAs after $T_{3}$ treatment. Stage 52 tadpoles were treated in $5 \mathrm{nM} \mathrm{T}_{3}$ water for various times in hours (HR) before RNA extraction. These RNAs were analyzed as in Fig. 3.

\section{Discussion}

Correlation of TRa and TR $\beta$ mRNAs with metamorphosis

The conservation of two distinct but closely related families of TH receptors, TR $\alpha$ and TR $\beta$, from mammals to chickens has now been extended to an amphibian, Xenopus. To date, the only clue that the two kinds of receptors may have distinct functions comes from correlation of their patterns of expression. In chicken, TR $\alpha$ mRNA expression is described as ubiquitous and constitutive, while TR $\beta$ mRNA increases at developmental periods and in specific tissues when the embryo is known to be sensitive to TH (Forrest et al. 1990). Expression of TR $\beta$ mRNA in rat brain by virtue of its cell type distribution and developmental pattern has suggested a developmental function (Bradley et al. 1989).

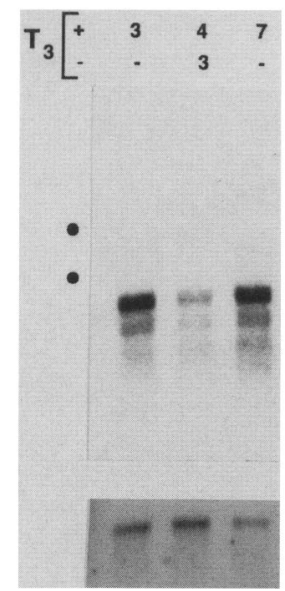

Figure 5. The down-regulation of TR $\beta$ gene expression after the withdrawal of $T_{3}$. Stage 52 tadpoles were maintained for 3 (left) or 7 (right) days in $5 \mathrm{nM} \mathrm{T} \mathrm{T}_{3}$ before RNA extraction. Tadpoles in $5 \mathrm{nM} \mathrm{T}_{3}$ for 4 days were washed and transferred to the frog water without $T_{3}$; RNA was extracted 3 days later (center). These RNAs were analyzed as in Fig. 3 . The filter was rehybridized to RP28 probe (lower bands).

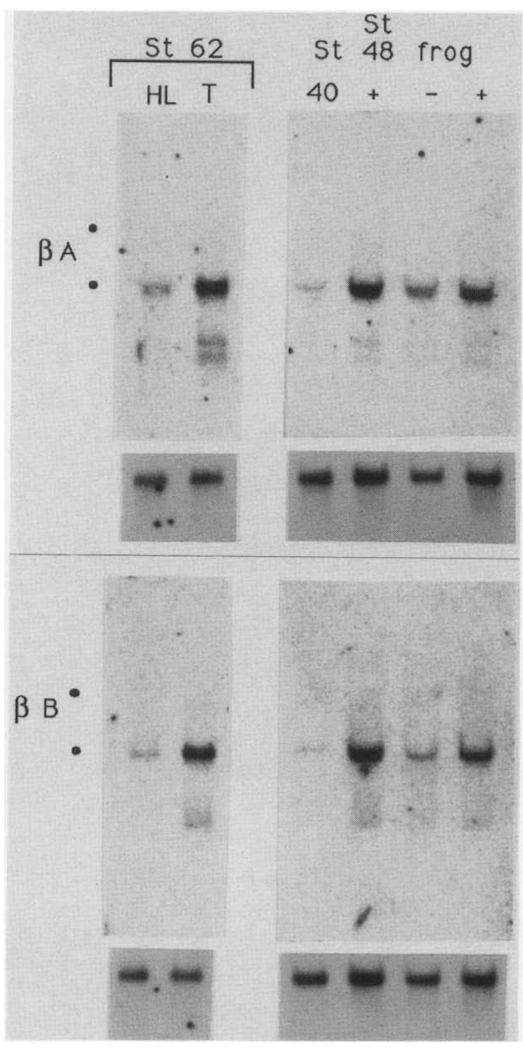

Figure 6. Expression of TR $\beta A$ and TR $\beta B$ genes. Total RNA $(10$ $\mu \mathrm{g}$ ) from hind limbs (HL) and tail (T) of stage 62 , stage 40 whole tadpoles, $\mathrm{T}_{3}$-treated stage 48 whole tadpoles, and livers of control and $\mathrm{T}_{3}$-treated frogs was reverse-transcribed into cDNAs that were electrophoresed, blotted, and hybridized to TR $\beta A$ - or TRßB-specific probes. Frogs were injected with $3 \times 10^{-10}$ moles/gram body weight of $\mathrm{T}_{3}$ and maintained in frog water containing $5 \mathrm{nM} \mathrm{T}$ for $24 \mathrm{hr}$. These filters were rehybridized to RP28 probe (lower bands).

There is one reported example of an alternatively spliced variant of TR $\beta$ (called TTR $\beta 2$ ) that is expressed only in the pituitary of the rat (Hodin et al. 1989). These reports correlate TR $\beta$ more than TR $\alpha$ with developmental control and tissue-specific expression. Recently, we demonstrated that there are two Xenopus TR $\beta$ genes, and their mRNAs undergo complex alternative splicing of as many as eight exons in the $5^{\prime}$-untranslated regions (Yaoita et al. 1990). This alternative splicing yields at least two different proteins at the amino terminus for both TR $\beta A$ and TR $\beta B$. Furthermore, the proteins vary at the same splice junction as the tissue-specific rat TR $\beta 2$ variant. We have not yet demonstrated tissue specificity for this alternative splicing, but there is a developmental change in mRNA complexity that could be explained by RNA splicing. A single reverse-transcribed cDNA band at early stages changes to two closely approximated bands after stage 52 (Figs. 2-4). This latter pattern is induced by TH (Fig. 3).

The pattern of developmental change of TR $\beta$ mRNA (Fig. 9) correlates with metamorphosis, especially the striking up-regulation of TR $\beta$ mRNA after administra- 


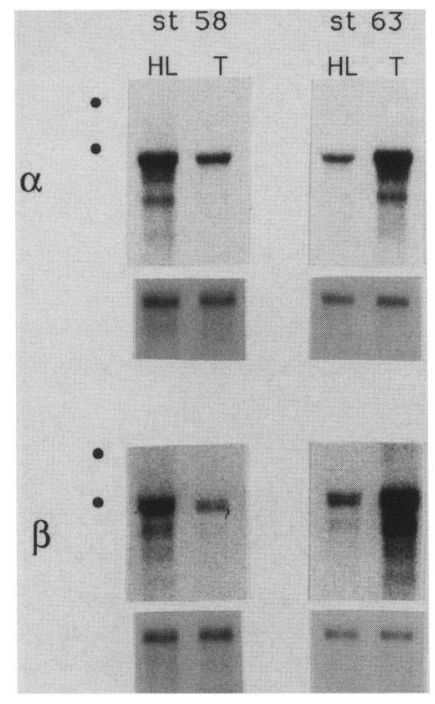

Figure 7. Expression of TR genes in hind limbs and tail at two stages. Total RNAs $(10 \mu \mathrm{g})$ extracted from hind limbs $(\mathrm{HL})$ and tail (T) of stage 58 and 63 tadpoles were used to synthesize cDNAs. After the analysis of TR $\alpha$ (upper) and TR $\beta$ (lower) gene expression, these filters were rehybridized with the RP28 probe (below the TR $\alpha$ and TR $\beta$ panels).

tion of $\mathrm{T}_{32}$. This up-regulation is already apparent $8 \mathrm{hr}$ after addition of $T_{3}$ to tadpoles in water (Fig. 4). We presume that the lag period before up-regulation would be shorter than $8 \mathrm{hr}$ if $\mathrm{T}_{3}$ were delivered more directly to tadpole cells by injection. Nonetheless, up-regulation of TR $\beta$ mRNA is the earliest TH-induced event yet detected. It precedes visible morphological changes by 2 days. A low level of TR $\beta$ mRNA is first detected in an embryo after hatching. Two days later, when TR $\beta$ mRNA can be up-regulated for the first time, a tadpole has become "competent" to respond to exogenous TH by undergoing morphological change. TR $\beta$ mRNA rises throughout prometamorphosis to its highest level at climax, paralleling closely the endogenous concentration of TH (Fig. 9). In contrast to TR $\beta$ mRNA, TR $\alpha$ mRNA levels rise during premetamorphosis before there is any detectable endogenous $T_{3}$ and remain elevated until after climax. We observed at most a two- to threefold up-regulation of TR $\alpha$ mRNA induced by TH in premetamorphosis.

During premetamorphosis, before the thyroid gland is formed, $\mathrm{T}_{3}$ must be administered continuously both for morphological changes to occur and to retain elevated amounts of TR $\beta$ mRNA (Fig. 5). The levels of both TR $\alpha$ and TR $\beta$ mRNA are higher in hind limbs when they are growing and in tail when it is regressing (Fig. 7). Another correlation of TR mRNA abundance with metamorphosis is the apparent higher TR mRNA levels in gills of the TH-responsive axolotl compared with those of the TH-resistant Necturus (Fig. 8). The former can metamorphose as a response to $\mathrm{TH}$, while the latter are refractory to the hormone. Some up-regulation of TR mRNA in axolotl gills was detected as a result of $\mathrm{TH}$ administration, which we presume represents TR $\beta$, but the Xenopus probes do not distinguish the TR $\alpha$ and TR $\beta$ gene families in these heterologous hybridization reactions. The satisfying conclusion that Necturus lacks one or all classes of TR mRNAs is tempered by the lack of a suitable control that would prove that this method can detect Necturus TR mRNAs should they exist.

Developmental Northern blots were reported by Baker and Tata (1990) throughout Xenopus development by use of chicken TR $\alpha$ and TR $\beta$ cDNA probes. Hybridization with the heterologous TR $\alpha$ probe from chicken detected mainly an abundant 4.2-kb RNA, which we have not detected; therefore, the hybridization assay of these investigators is measuring something different from our own. Their TR $\beta$ mRNA analysis was limited to slot blot hybridization, but showed greater hybridization at stage 61 than at stage 58 (as we have found). However, they report that TR mRNA levels were unaffected by TH administration.

\section{Up-regulation of TR $\beta$ mRNA}

Hormones can influence gene expression by transcriptional or post-transcriptional control mechanisms. An example of a ligand up-regulating the mRNA encoding its own receptor is the transcriptional up-regulation of the human $\beta$-retinoic acid receptor by retinoic acid (de Thé et al. 1989, 1990). Estrogen can both stabilize vitellogenin mRNA and regulate its transcription (Shapiro et al. 1984). Estrogen also up-regulates estrogen receptor mRNA (Barton and Shapiro 1988). TH has been reported to down-regulate TR $\alpha$ mRNA in the rat (Strait et al. $1990)$ and to down-regulate the pituitary-specific TR $\beta 2$ (Hodin et al. 1989).

There have been several studies correlating the binding of radioactive $T_{3}$ to various tadpole tissues during metamorphosis as a measure of functional re-

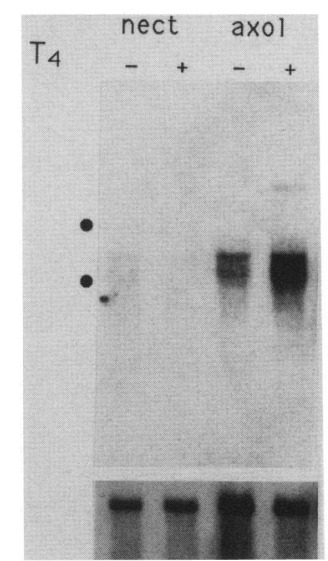

Figure 8. Expression of TR genes in gills of neotenic salamanders. The cDNAs were prepared from $10 \mu \mathrm{g}$ of total RNA from gills of axolotl and Necturus control or $\mathrm{T}_{3}$-injected animals. The cDNAs were electrophoresed, blotted, and hybridized to a Xenopus TR $\beta$ probe (upper panel) and then to the RP28 probe (lower panel). In both cases, the filter was washed with $2 \times$ SSC at room temperature twice and then with $0.1 \times$ $\mathrm{SSC}-0.1 \%$ SDS at $50^{\circ} \mathrm{C}$ for $10 \mathrm{~min}$. 


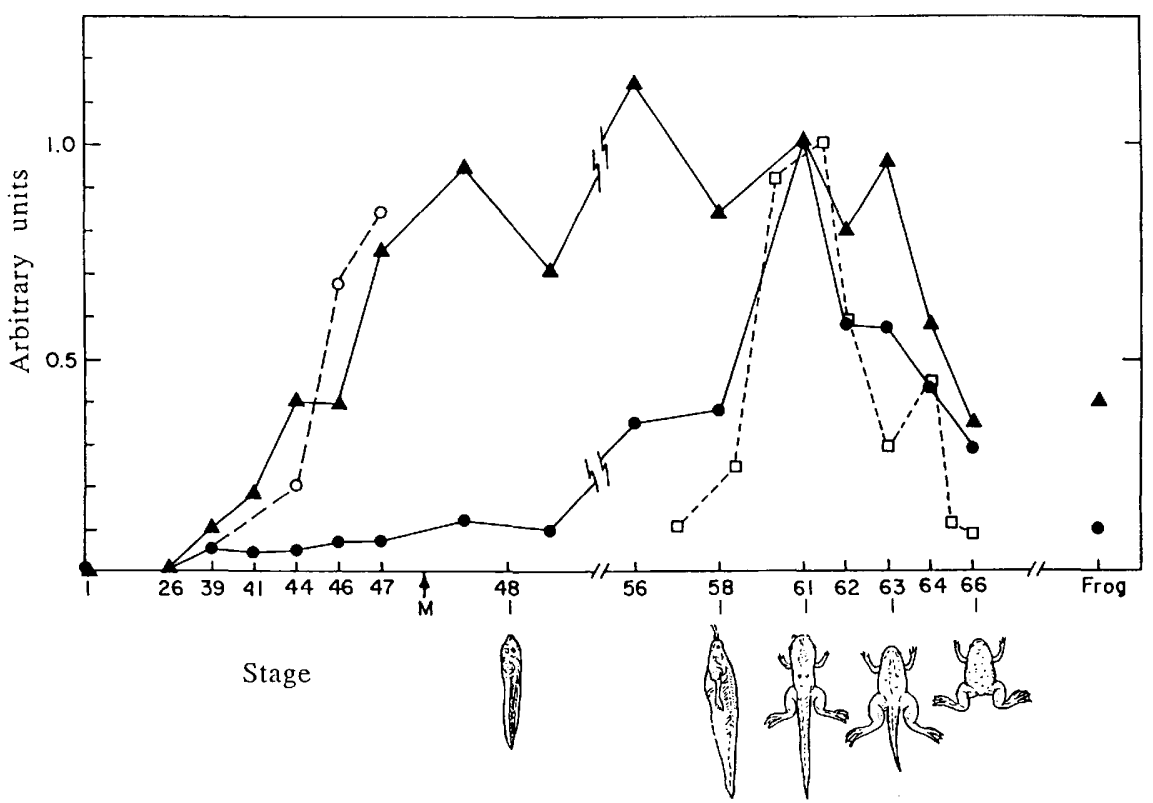

Figure 9. A summary of the developmental expression of TR $\alpha$ and TR $\beta$ genes throughout embryogenesis, tadpole growth, and metamorphosis. Stages of development of $X$. laevis embryos and tadpoles (Nieuwkoop-Faber 1956) with representative pictures are plotted against the amounts of $\operatorname{TR} \alpha(\mathbf{\Delta})$ and TR $\beta(\mathbf{O})$ cDNAs and $T_{3}(\square)$ (Leloup and Buscaglia 1977) in arbitrary units, calling the amount at stage 61 as 1.0. Quantitation of band density (Fig. 2) was measured by densitometry using preflashed film. Values were corrected for the abundance of the RP28 mRNA, which was assumed to be constant throughout development (after hatching). The levels of TR $\beta$ cDNA $(O)$ in tadpoles up-regulated by exogenous $T_{3}$ during premetamorphosis are also shown. An arrow (M) indicates the time when the first morphological change induced by $\mathrm{T}_{3}$ was detected.

ceptor. Galton (1984; Galton and St. Germain 1985) has found that the binding of red blood cells to $\left[{ }^{125} \mathrm{I}\right] \mathrm{T}_{3}$ rises threefold from early prometamorphosis to a peak at climax in Rana catesbeiana and then falls. This level of binding is up-regulated by exogenous $\mathrm{T}_{3}$. A similar result has been described for red blood cells by Moriya et al. (1984) and for tadpole tail (Yoshizato and Frieden 1975).

Whether up-regulation of TR $\beta$ mRNA is due to transcriptional or post-transcriptional mechanisms remains to be elucidated, but features of the mRNAs suggest an involvement of translational control in the expression of both TR $\alpha$ and TR $\beta$ (Yaoita et al. 1990). We have shown that the 5' UTR of TR $\beta$ mRNA consists of at least eight variably spliced exons containing a number of small open reading frames (ORFs). The $5^{\prime}$ UTRs of TR $\alpha$ mRNAs also contain a small ORF adjoining the true translation start site. The $5^{\prime}$ UTR length $1 \sim 600$ bp for TR $\alpha$ and $200-600 \mathrm{bp}$ for TR $\beta$ ) is unusually long (Kozak 1987), but the 3' UTRs, which have not yet been characterized, are among the longest yet found in eukaryotic mRNAs $-\sim 8 \mathrm{~kb}$ in length (Fig. 1). The presence of ORFs in the 5' UTRs can regulate the translation efficiency of these mRNAs (Mueller and Hinnebusch 1986). The quantities of TR $\alpha$ and TR $\beta$ mRNAs have been estimated by comparing band intensity of the reverse-transcribed products with those of Southern blots of known quantities of genomic DNA (data not shown). Even at the highest levels of TR $\beta$ mRNA (stage 61), there are three times as many molecules of TR $\alpha$ mRNA than of TR $\beta$ mRNA in total RNA extracted from whole animals. We estimate $\sim 30$ copies per cell of TR $\alpha$ mRNA at climax.
Competence and the first step of the metamorphosis cascade

We have presented no functional evidence that TR $\alpha$ and/or TR $\beta$ are intermediates in metamorphosis. These studies are only correlative in nature and to date have only measured mRNA levels, not the proteins that they encode. Even these mRNA measurements lose detail because mainly total tadpole RNA rather than individual tissues were studied. However, these measurements suggest two obvious insights into the first steps of metamorphosis. The first is a simple explanation for the phenomenon of "competence" (Tata 1968), that is, the ability of growing tadpoles to respond precociously to exogenous TH. Competence correlates with the synthesis of TR mRNAs, especially the ability of exogenous TH to up-regulate TR $\beta$ mRNA. Second, we note that TR $\alpha$ mRNA accumulates during premetamorphosis but TR $\beta$ mRNA remains low until endogenous $T_{3}$ is synthesized. It has been demonstrated that TR proteins repress TH-responsive genes in the absence of TH (Damm et al. 1989; Forman et al. 1989). By analogy, perhaps the cascade of metamorphosis is repressed during premetamorphosis in a competent tadpole by TR $\alpha$ protein binding to response elements in the TR $\beta$ genes. Hypothetically, this repression would be relieved by TH during prometamorphosis up-regulating the expression of TR $\beta$, which, in turn, activates (or represses) the downstream genes in the cascade. We imagine that the first downstream set of genes encodes tissue-specific transcription factors, which then activate the many genes whose products ac- 
count for the global morphological and biochemical changes that characterize the transition from tadpole to frog.

\section{Materials and methods}

\section{Animals}

Xenopus laevis embryos were raised in dechlorinated tap water (frog water) and fed with nettle powder. Staging of embryos was according to the table of Nieuwkoop and Faber (1956). Metamorphosis was induced by adding $5 \mathrm{nM} \mathrm{T}_{3}$ to frog water. The frog water was changed daily. Adult axolotl were obtained from the axolotl center at Indiana University. Necturus were purchased from Charles Sullivan Company. Axolotl and Necturus were injected intraperitoneally once with $0.3 \mu \mathrm{g}$ of thyroxine/ gram of body weight (Norris and Platt 1974) and maintained in $26 \mathrm{nM}$ thyroxine $\left(\mathrm{T}_{4}\right)$ for 2 days before total RNA was extracted from their gills.

\section{RNA isolation, blotting, and hybridization}

A single mating provided tadpoles for each developmental series. RNA was extracted from $10-50$ pooled tadpoles at each time or developmental stage. Whole tadpoles or tissues were homogenized in guanidinium thiocyanate /Chirgwin et al. 1979). The homogenate was centrifuged briefly to remove debris and aggregates. RNA was separated from DNA and proteins by cesium chloride centrifugation and then extracted with phenol and chloroform. The poly $(\mathrm{A})+$ RNA fraction was obtained by passing total RNA over an oligo(dT)-cellulose column and eluting with a low-salt buffer. RNAs were denatured in the presence of glyoxal and DMSO and subjected to electrophoresis in an agarose gel. RNAs were blotted onto Nytran (Schleicher \& Schuell), UV cross-linked, and baked in a vacuum oven at $80^{\circ} \mathrm{C}$ for $3 \mathrm{hr}$. The filter was hybridized with a labeled probe and washed with two changes of $2 \times$ SSC at room temperature, $0.1 \times$ SSC $-1 \%$ SDS at $65^{\circ} \mathrm{C}$ for $1 \mathrm{hr}$, and two changes of $0.1 \times$ SSC $-0.1 \%$ SDS at $65^{\circ} \mathrm{C}$ for 15 min each. In our experience, $\mathrm{Ny}-$ tran filters have a high retention efficiency for RNA.

\section{Modified primer extension assay}

The cDNA was synthesized from total RNA by avian reverse transcriptase primed with gene-specific antisense oligonucleotides: 5'-(1346)ATTGTCTTCTTAGGATAT(1329)-3' (for TR $\alpha$ ) or $5^{\prime}-(1341)$ GCCAAACACACTGCTTGT(1324)-3' (for TR $\beta$ ). Numbers in parentheses locate the positions of the antisense primers, counting the adenine of the initiation codon in the TR $\alpha$ gene as one, or the guanine adjacent to the "changing point" of TR $\beta$ gene, which is located at the 5 ' end of the first zinc finger in the TR $\beta$ gene (Yaoita et al. 1990). Although there are two nucleotide differences in this region between TR $\beta A$ and TR $\beta B$, this oligonucleotide primes cDNA synthesis from both mRNAs with the same efficiency under these conditions /data not shown). The cDNA was extracted in phenol and chloroform, precipitated with ethanol, denatured by DMSO and glyoxal, fractionated by an agarose gel, and transferred to $\mathrm{Ny}$ tran filters. The hybridization procedure is described above.

Xenopus TR $\alpha$ and TR $\beta$ probes were prepared from cDNA inserts $(556-1212)$ for TR $\alpha B$ and $(122-1428)$ for TR $\beta A$ cDNA clones by nick-translation or random primer labeling methods. The former fragment contains the junction region (between the DNA-binding and thyroid hormone-binding domain) and the thyroid hormone-binding domain; the latter fragment contains the same regions but, in addition, the second zinc finger and part of the $3^{\prime}$-untranslated region. The TR $\alpha$ and TR $\beta$ probes hybridized to TR $\alpha \mathrm{A}$ and $\mathrm{TR} \alpha \mathrm{B}$ and TR $\beta A$ and TR $\beta \mathrm{B}$, respectively, in Southern blots of genomic DNA. The TR $\alpha$ probe does not cross-hybridize with the TR $\beta$ probe by use of stringent hybridization conditions. The TR $\beta A$ - and TR $\beta B$-specific probes were prepared from the first zinc finger fragment of TR $\beta A$ and TR $\beta B$ genes, respectively, by a repetitive polymerase labeling method (Yaoita et al. 1990).

The amounts of RNA from each embryo stage were standardized by rehybridizing the filters with a cDNA (PR28) that encodes a Xenopus RNA that is constitutively expressed after stage 35 (Shi and Brown 1990). The primer extension reaction used to prepare TR cDNA does not degrade the PR2 28 mRNA, and the level of this mRNA is not influenced by $T_{3}$. The PR28 cDNA also hybridizes to Necturus and axolotl mRNA (Fig. 8). PR28 has not been sequenced. Band densities were traced with a densitometer from the autoradiogram of a preflashed film.

\section{Acknowledgments}

We thank our colleagues for their many helpful criticisms. This research was supported, in part, by grants from the National Institutes of Health and the Lucille P. Markey Charitable Trust.

The publication costs of this article were defrayed, in part, by payment of page charges. This article must therefore be hereby marked "advertisement" in accordance with 18 USC section 1734 solely to indicate this fact.

\section{References}

Baker, B.S. and J.R. Tata 1990. Accumulation of proto-oncogene c-erb-A related transcripts during Xenopus development: Association with early acquisition of response to thyroid hormone and estrogen. EMBO J. 9: 879-885.

Barton, M.C. and D.J. Shapiro. 1988. Transient administration of estradiol-17 $\beta$ establishes an autoregulatory loop permanently inducing estrogen receptor mRNA. Proc. Natl. Acad. Sci. 85: 7119-7123.

Bradley, D.J., W.S. Young III, and C. Weinberger. 1989. Differential expression of $\alpha$ and $\beta$ thyroid hormone receptor genes in rat brain and pituitary. Proc. Natl. Acad. Sci. 86: 72507254.

Chirgwin, J.M., A.E. Przybyla, R.J. MacDonald, and W.J. Rutter. 1979. Isolation of biologically active ribonucleic acid from sources enriched in ribonuclease. Biochemistry 18: 52945299.

Damm, K., C.C. Thompson, and R.M. Evans. 1989. Protein encoded by v-erbA functions as a thyroid-hormone receptor antagonist. Nature 339: 593-597.

Dent, J.N. 1968. Survey of amphibian metamorphosis. In Metamorphosis (ed. W. Etkin and L.I. Gilbert), pp. 271-311. Appleton-Century-Crofts, New York.

de Thé, H., A. Marchio, P. Tiollais, and A. Dejean. 1989. Differential expression and ligand regulation of the retinoic acid receptor $\alpha$ and $\beta$ genes. EMBO J. 8: 429-433.

de Thé, H., M. del Mar Vivanco-Ruiz, P. Tiollais, H. Stunnenberg, and A. Dejean. 1990. Identification of a retinoic acid responsive element in the retinoic acid receptor $\beta$ gene. $\mathrm{Na}$ ture 343: $177-180$.

Dodd, M.H.I. and J.M. Dodd. 1976. The biology of metamorphosis. In Physiology of the amphibia (ed. B. Lofts), vol. III, pp. 467-599. Academic Press, New York.

Etkin, W. 1968. Hormonal control of amphibian metamorphosis. In Metamorphosis (ed. W. Etkin and L.I. Gilbert), pp. 313-348. Appleton-Century-Crofts, New York.

Forman, B.M., C. Yang, M. Au, J. Casanova, J. Ghysdael, and 
H.H. Samuels. 1989. A domain containing a leucine zipperlike motif mediates novel in vivo interactions between the thyroid hormone and retinoic acid receptors. Mol. Endocrinol. 3: 1610-1626.

Forrest, D., M. Sjöberg, and B. Vennström. 1990. Contrasting developmental and tissue-specific expression of $\alpha$ and $\beta$ thyroid hormone receptor genes. EMBO J. 9: 1519-1528.

Galton, V.A. 1984. Putative nuclear triiodothyronine receptors in tadpole erythrocytes: Regulation of receptor number by thyroid hormone. Endocrinology 114: 735-742.

Galton, V.A. and D.L. St. Germain. 1985. Putative nuclear triiodothyronine receptors in tadpole erythrocytes during metamorphic climax. Endocrinology 116: 99-104.

Hodin, R.A., M.A. Lazar, B.I. Wintman, D.S. Darling, R.J. Koenig, P.R. Larsen, D.D. Moore, and W.W. Chin. 1989. Identification of a thyroid hormone receptor that is pituitary-specific. Science 244: 76-79.

Kollros, J.J. 1961. Mechanisms of amphibian metamorphosis: Hormones. Am. Zool. 1: 107-114.

Kozak, M. 1987. An analysis of 5'-noncoding sequences from 699 vertebrate messenger RNAs. Nucleic Acids Res. 15: $8125-8148$.

Kühn, E.R. and G.F.M. Jacobs. 1989. Metamorphosis. In Developmental biology of the axolotl (ed. J.B. Armstrong and G.M. Malacinski), pp. 187-197. Oxford University Press, New York.

Leloup, J. and M. Buscaglia. 1977. La triiodothyronine, hormone de la métamorphose des amphibiens. C.R. Acad. Sci. Paris 284D: 2261-2263.

Moriya, T., C.R. Thomas, and E. Frieden. 1984. Increase in 3,5,3'-triiodothyronine $\left(\mathrm{T}_{3}\right)$-binding sites in tadpole erythrocyte nuclei during spontaneous and $\mathrm{T}_{3}$-induced metamorphosis. Endocrinology 114: 170-175.

Mueller, P.P. and A.G. Hinnebusch. 1986. Multiple upstream AUG codons mediate translational control of GCN4. Cell 45: 201-207.

Nieuwkoop, P.D. and J. Faber. 1956. Normal table of Xenopus laevis. North-Holland Publishing Company, Amsterdam.

Norris, D.O. and J.E. Platt. 1974. $\mathrm{T}_{3^{-}}$and $\mathrm{T}_{4}$-induced rates of metamorphosis in immature and sexually mature larvae of Ambystoma tigrinum (Amphibia: Caudata). I. Exp. Zool. 189: 303-310.

Shapiro, D.J., J.E. Blume, and D.A. Nielsen. 1984. Regulation of messenger RNA stability in eukaryotic cells. BioEssays 6: $221-226$.

Shi, Y.-B. and D.D. Brown. 1990. Developmental and thyroid hormone dependent regulation of pancreatic genes in Xenopus laevis. Genes Dev. 4: 1107-1113.

Strait, K.A., H.L. Schwartz, A. Perez-Castillo, and J.H. Oppenheimer. 1990. Relationship of c-erbA mRNA content to tissue triiodothyronine nuclear binding capacity and function in developing and adult rats. $\%$ Biol. Chem. 265: $10514-10521$.

Tata, J.R. 1968. Early metamorphic competence of Xenopus larvae. Dev. Biol. 18: 415-440.

Yaoita, Y., Y.-B. Shi, and D.D. Brown. 1990. The Xenopus laevis alpha and beta thyroid hormone receptors. Proc. Natl. Acad. Sci. 87: 7090-7094.

Yoshizato, K. and E. Frieden. 1975. Increase in binding capacity for triiodothyronine in tadpole tail nuclei during metamorphosis. Nature 254: 705-707. 


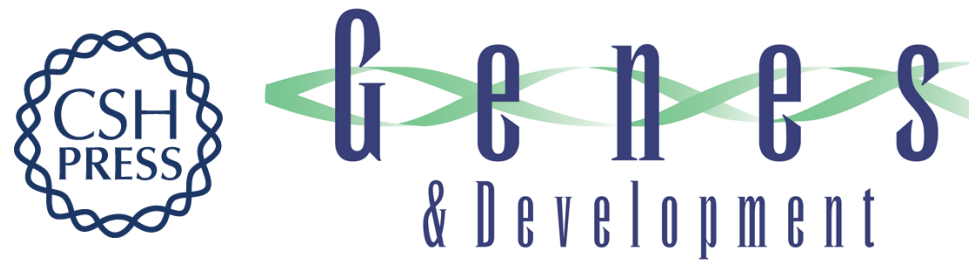

\section{A correlation of thyroid hormone receptor gene expression with amphibian metamorphosis.}

Y Yaoita and D D Brown

Genes Dev. 1990, 4:

Access the most recent version at doi:10.1101/gad.4.11.1917

References This article cites 24 articles, 6 of which can be accessed free at:

http://genesdev.cshlp.org/content/4/11/1917.full.html\#ref-list-1

License

Email Alerting

Service

Receive free email alerts when new articles cite this article - sign up in the box at the top right corner of the article or click here.

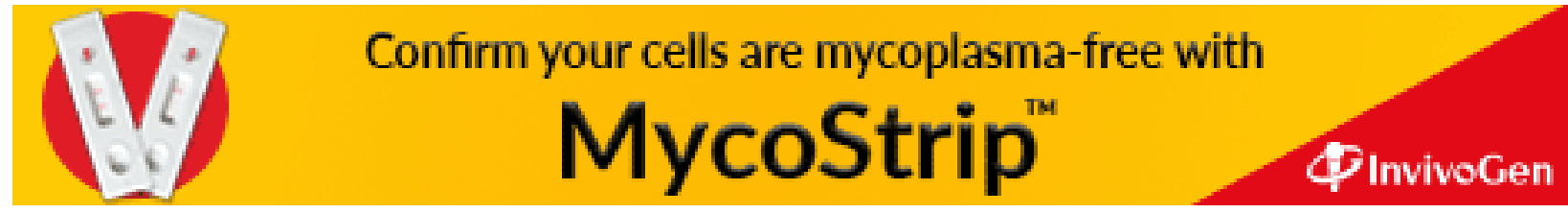

